\title{
Diatom to dinoflagellate shift in the summer phytoplankton community in a bay impacted by nuclear power plant thermal effluent
}

\author{
Tao $\mathrm{Li}^{1,2}$, Sheng Liu ${ }^{1, *}$, Liangmin Huang ${ }^{1}$, Hui Huang ${ }^{1,2}$, Jiansheng Lian ${ }^{1,3}$, \\ Yan Yan ${ }^{1,3}$, Senjie Lin ${ }^{1,4}$ \\ ${ }^{1}$ Key Laboratory of Marine Bio-Resources Sustainable Utilization, South China Sea Institute of Oceanology, \\ Chinese Academy of Sciences, Guangzhou 510301, China \\ ${ }^{2}$ Tropical Marine Biological Research Station in Hainan, Chinese Academy of Sciences, Sanya 572000, China \\ ${ }^{3}$ Marine Biology Research Station at Daya Bay, Chinese Academy of Sciences, Shenzhen 518121, China \\ ${ }^{4}$ Department of Marine Sciences, University of Connecticut, Groton, Connecticut 06340, USA
}

\begin{abstract}
Understanding how nuclear power plant thermal effluents influence the phytoplankton community may provide insights into the potential ecological consequences of global warming. In the present study, long-term trends in the phytoplankton community structure under the influence of nuclear power plant thermal effluent in the subtropical Daya Bay (DYB) in China were investigated in the summer season from 1982 to 2005 . Water temperature at the outfall station was significantly higher than in the surrounding water, by as much as $5.6^{\circ} \mathrm{C}$, and increased by $6.8^{\circ} \mathrm{C}$ during the $23 \mathrm{yr}$ study period. The contribution of diatoms and dinoflagellates to the total phytoplankton showed significant correlation with temperature $\left(\mathrm{R}^{2}>0.65\right)$, negative for diatoms, while positive for dinoflagellates. Although dinoflagellate abundance increased over time at both the outfall and adjacent (control) stations, the increase at the outfall station was much more dramatic and accelerated over time. No clear relationship between the phytoplankton shift and stratification was evident. When water temperature reached $35^{\circ} \mathrm{C}$ or $>3.7^{\circ} \mathrm{C}$ above that at the control station, dinoflagellates, such as Ceratium furca, C. fusus, C. trichoceros, Dinophysis caudate and Protoperidinium depressum, grew to prominence, accounting for about $50 \%$ of the total phytoplankton abundance. On the contrary, the diatom contribution decreased during the study period, from $82.0 \%$ in 1982 to $53.1 \%$ in 2005 . These results suggest that the rise in temperature caused by power plant thermal discharge has imposed strong influences on the phytoplankton community, favoring dinoflagellates over diatoms, with a remarkable diatom to dinoflagellate shift when temperature increases to a threshold level of $35^{\circ} \mathrm{C}$ or reaches a threshold differential of $3.7^{\circ} \mathrm{C}$ relative to the normal ambient temperature in DYB.
\end{abstract}

KEY WORDS: Daya Bay $\cdot$ Nuclear power plant $\cdot$ Thermal effluent $\cdot$ Phytoplankton $\cdot$ Ecological effects

\section{INTRODUCTION}

Over the past $100 \mathrm{yr}$, the earth's surface temperature has increased by about $0.75^{\circ} \mathrm{C}$ and the sea-surface temperature (SST) has increased by about $0.5^{\circ} \mathrm{C}$ (IPCC 2007). In tropical oceans, the SST has increased by about 1 to $2^{\circ} \mathrm{C}$ during the last century (Hoegh-Guldberg 1999). In the South China Sea, the SST has increased by about $0.016^{\circ} \mathrm{C} \mathrm{yr}^{-1}$ from 1950 to 2006 in the central waters (Cai et al. 2009) and by about 0.019 to $0.034^{\circ} \mathrm{C} \mathrm{yr}^{-1}$ from 1971 to 2003 in northern waters (Tang et al. 2006). The rise in temperature is widely believed to exert impacts on almost all organisms with respect to their distribution, survival, growth, reproduction, metabolism and even their life cycle (Eloranta 1983). For phytoplankton, the effects of a rise in tem- 
perature can be indirect, via a decrease in the resupply of nutrients for phytoplankton production resulting from the intensification of water stratification (Margalef 1978, Jones \& Gowen 1990). Since phytoplankton have short generation times, they can rapidly respond to temperature increases, and, because they are at the base of the aquatic food web, observations of their responses could provide useful insights into how temperature increases may induce ecosystem changes (Niemi \& McDonald 2004). Phytoplankton community structure and abundance have been found to be changing as a result of global warming in many areas (Richardson \& Schoeman 2004). For example, the changes in phytoplankton communities have been used as indicators of global warming in the North Sea (Edwards \& Richardson 2004) and to monitor nonnative, warm-water species in the Mediterranean and the North Seas (Walther et al. 2002). Because organisms at different trophic levels may not respond synchronously to temperature increases, changes in phytoplankton can cause trophic mismatching in the food chain (Edwards \& Richardson 2004), ultimately affecting fish recruitment and output (Beaugrand et al. 2003). Over the last decades there has been growing concern about the trophic cascade effects of global warming (Edwards \& Richardson 2004).

The effects of increased temperatures on phytoplankton appear to be highly spatially heterogeneous and species specific (Krishnakumar et al. 1991, Richardson \& Schoeman 2004). Temperature increases could cause phytoplankton abundance increases or community shifts in temperate regions, such as the North Sea (Beaugrand et al. 2003) or the Northeast Atlantic (Richardson \& Schoeman 2004), but decreases in phytoplankton abundance in subtropical and tropical waters (Richardson \& Schoeman 2004), where the temperature is very close to the upper tolerance limit for many organisms and a small temperature elevation may exceed the physiological tolerances of organisms (Walther et al. 2002). Even though influences of the rise of temperature on phytoplankton community structure, abundance and distribution have been studied for decades (e.g. Edwards \& Richardson 2004, Hays et al. 2005), many questions still remain, especially regarding the trend of changes in the phytoplankton community (Richardson \& Schoeman 2004).

The thermal effluent from power plants inevitably elevates the temperature of the receiving waters. In practice, it offers an excellent model to examine the potential effects of global warming on aquatic ecosystems. The effects of thermal effluents on phytoplankton might be different, depending on the hydrodynamics and phytoplankton community structure of the impacted waters. In well-mixed waters, such as estuarine and coastal waters, where heat is dispersed very quickly, the influence may be modest. For example, no significant effluent effects on phytoplankton were detected in the Parana River (Mercado \& Gomez 1999) or in the well-mixed zone north of Taiwan (Lo et al. 2004), and little influence to the Meuse River was noted for the Tihange nuclear power plant (Descy \& Mouvet 1984). However, if thermal discharge is directed into enclosed water bodies (e.g. ponds, reservoirs and lakes), it can create a notable impact due to slow heat dispersal (Eloranta 1983, Gomez 1995).

Daya Bay (DYB) is a subtropical semi-enclosed bay situated in the northern South China Sea, very close to Hong Kong. Its area is about $550 \mathrm{~km}^{2}$, and its depth in most parts is <10 m (Xu 1989). It is hydrodynamically dominated by semidiurnal tides, and the average resident time of the surface water is about $3.2 \mathrm{~d}$ (Zhang \& Zhou 2004). There are no major rivers around DYB, with most of its water coming from the South China Sea (Xu 1989). DYB harbors 2 nuclear power stations (NPS). The DYB nuclear power station (DNPS; $2 \times 900 \mathrm{MW}$ ) and the Ling-Ao nuclear power station (LNPS; $4 \times 900 \mathrm{MW}$ ) were located on the northwest coast of DYB. DNPS has been operating since February 1994 and releases about $95 \mathrm{~m}^{3} \mathrm{~s}^{-1}$ thermal effluent to DYB (Chen et al. 1996). The first power unit (900 MW) of the LNPS has been in operation since May 2002, and the second (900 MW) since January 2003. Their total thermal effluent is also about $95 \mathrm{~m}^{3} \mathrm{~s}^{-1}$. The SST is around $30^{\circ} \mathrm{C}$ in DYB in summer (Xu 1989), which is near the upper tolerance limit of phytoplankton growth. Huang et al. (1998) reported that the summer mean water temperature has increased by $2.30^{\circ} \mathrm{C}$ since the inception of the DNPS operation. The thermal effluent has substantially influenced the ecosystem of DYB, especially in summer, when stratification aggravated the influence of the thermal effluent in surface waters (Wang et al. 2003). The phytoplankton community was mainly composed of coastal warm-water species in DYB, with a low diversity in summer, especially in the waters near the NPS (Sun et al. 2006). However, all previous studies in DYB were mostly based on short-term data and no long-term trends have been studied; thus, the potential effect of water stratification has not been considered. The objective of the present study was to evaluate the long-term effects of thermal effluent on the phytoplankton community in DYB, with a primary focus on the summer season (from July to August). Phytoplankton communities in the discharge area and its adjacent areas were compared over a 23 yr period (1982 to 2005), and their correlations with temperature and other environmental variables were analyzed to better understand how the phytoplankton community responds to long-term exposures to thermal effluent. 


\section{MATERIALS AND METHODS}

Data collection. Data were collected from 1982 to 2005 in a survey by the Marine Biological Research Station, South China Sea Institute of Oceanology, Chinese Academy of Sciences. In each year, sampling occurred seasonally, in April (spring), July or August (summer), October (autumn), and January (winter). Sampling stations covered almost the whole bay (Fig. 1). Environmental factors examined included temperature, salinity, nitrate, nitrite, ammonium, phosphate and silicate from surface and bottom waters, as well as depth and transparency at each station (Table 1). For phytoplankton analysis, $500 \mathrm{ml}$ water samples were collected from the surface. Subsamples of $50 \mathrm{ml}$ were concentrated to $1 \mathrm{ml}$ using the Utermöhl settling method, and phytoplankton were identified and enumerated in a Sedgwick-Rafter counting chamber with an inverted Olympus BX51 microscope.

Vertically averaged potential energy anomaly. The vertically averaged potential energy anomaly $\left(\mathrm{PEA}_{i} \varphi\right.$, $\mathrm{J} \mathrm{m}^{-3}$ ) is the energy for vertical mixing of the water column. It is directly related to the strength of stratification. In the present study, it was used to indicate the stratification index at all survey stations and was calculated as follows (Jones \& Gowen 1990):

$$
\varphi=1 / h \int_{-h}^{0}(\bar{\rho}-\rho) g \cdot z \cdot d z
$$

Therein,

$$
\bar{\rho}=1 / h \int_{-h}^{0} \rho \cdot d z
$$

where $h$ is the water column depth (m), $\rho$ is the density of seawater $\left(\mathrm{kg} \mathrm{m}^{-3}\right)$ at depth $z$ and $g$ is the acceleration due to gravity $\left(\mathrm{m} \mathrm{s}^{-2}\right)$.
Table 1. Measurements and methods used (UNESCO 1994). mo: ammonium molybdate

\begin{tabular}{|ll|}
\hline Parameter & Method \\
\hline Depth & Sonar \\
Transparency & Secchi disk \\
Temperature & Thermometer \\
Salinity & Salinometer \\
Nitrate $\left(\mathrm{NO}_{3}-\mathrm{N}\right)$ & Cu-Cd reduction \\
Nitrite $\left(\mathrm{NO}_{2}-\mathrm{N}\right)$ & Diazonium coupling \\
Ammonium $\left(\mathrm{NH}_{4}-\mathrm{N}\right)$ & Phenolhypochlorite \\
Phosphate $\left(\mathrm{PO}_{4}-\mathrm{P}\right)$ & Phosphorus-mo-blue extraction \\
Silicate $\left(\mathrm{SiO} \mathrm{O}_{4}-\mathrm{Si}\right)$ & Silicon-mo-blue extraction \\
Phytoplankton & Light microscopy \\
\hline
\end{tabular}

Data analysis. SPSS Ver. 15.0 was employed for data analysis. Correlation analysis (CA) was used to determine the relationship between phytoplankton (species number and cell abundance) and environmental factors (temperature, salinity, PEA and nutrients) in different seasons. Principal component analysis (PCA) was employed to identify the loading of each factor (Singh et al. 2004), and stations were selected for further analysis based on the major PCA factor. Specifically, CA was used to calculate the linear correlation coefficients between 10 ecological parameters, including temperature, salinity, PEA, dissolved inorganic nitrogen (DIN), dissolved inorganic phosphorus (DIP), silicate, percentage of diatom species (P1), percentage of dinoflagellate species (P2), percentage of diatom cell abundance (P3) and percentage of dinoflagellate cell abundance (P4). PCA began by standardizing the original variables, calculating the covariance or correlation matrix and the latent root and eigenvector of the

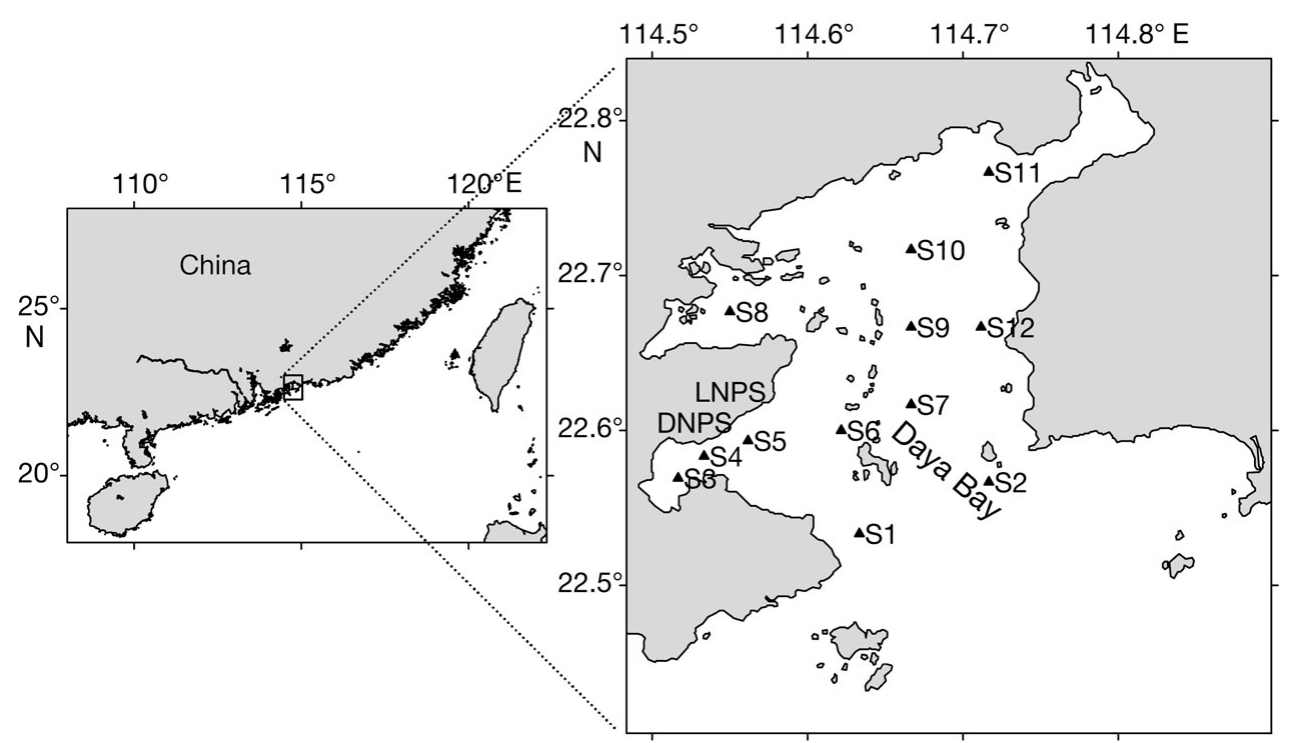

Fig. 1. Study site and sampling stations. DNPS: Daya Bay nuclear power station; LNPS: Ling-Ao nuclear power station; S5: outfall station; S6: control station 
covariance matrix, and then confirming the principal components (PCs). Finally, the PC information was interpreted in the context of the environmental setting used in the present study. One-way ANOVA was used to test the difference for the phytoplankton community and environmental factors between the stations selected for further analysis.

\section{RESULTS}

\section{Identification of major factors}

Phytoplankton variables (P1, P2, P3 and P4) were significantly correlated with temperature in summer only, but not with salinity or nutrients (DIN, DIP and silicate) in general. Because no correlation was found for other seasons, further analysis was focused on the summer dataset. Based on PCA, the eigenvalues of the first 3 PCs were $>1$, which explained $81.561 \%$ of the total variation, i.e. the sum of the variances of the 10 original variables (Table 2$)$. PC1 $(50.328 \%$ of the total variation) was mainly contributed by temperature and phytoplankton-related variables, showing the impor-

Table 2. Loadings of 10 parameters on the first 3 principal components (PCs; from 1994 to 2005). PEA: potential energy anomaly; DIN: dissolved inorganic nitrogen; DIP: dissolved inorganic phosphorus; P1: percentage of diatom species; P2: percentage of dinoflagellate species; P3: percentage of diatom cell abundance; P4: percentage of dinoflagellate cell abundance

\begin{tabular}{|lrrr|}
\hline & PC1 & PC2 & \multicolumn{1}{c|}{ PC3 } \\
\hline Temperature & 0.942 & -0.052 & 0.156 \\
Salinity & 0.504 & 0.480 & -0.458 \\
PEA & -0.215 & -0.710 & -0.359 \\
DIN & 0.404 & 0.822 & -0.075 \\
DIP & -0.377 & -0.034 & 0.714 \\
Silicate & -0.574 & 0.181 & 0.604 \\
P1 & -0.907 & -0.059 & -0.240 \\
P2 & 0.895 & 0.002 & 0.305 \\
P3 & -0.891 & 0.366 & -0.084 \\
P4 & 0.891 & -0.356 & 0.099 \\
Eigenvalue & 5.033 & 1.712 & 1.412 \\
Variance (\%) & 50.328 & 17.117 & 14.116 \\
Cumulative (\%) & 50.328 & 67.445 & 81.561 \\
\hline
\end{tabular}

tance of temperature, the loading of which was 0.942 . Temperature was identified as the most important factor having an impact on phytoplankton community at the outfall station.

\section{Station selection}

During the study period, the average DIN, DIP and silicate in DYB were somewhat lower than in other bays in China (Wang et al. 2003), but still much higher than the limitation thresholds for phytoplankton growth (1 $\mu \mathrm{M}$ for DIN, $0.1 \mu \mathrm{M}$ for DIP and $2 \mu \mathrm{M}$ for silicate, respectively; Justić et al. 1995). It has been reported that the nutrient conditions in DYB could meet the demand of phytoplankton growth (Liu et al. 2003, 2006).

PCA was also conducted based on the summer SST in different years. Survey stations were clearly divided into 2 groups (Fig. 2a). S5 formed an independent group well separated from the other stations that clustered in another group. S5 was in the waters receiving thermal effluent (Fig. 1), and thus had a different temperature range from the other stations.

Therefore, S5 was chosen as the temperatureimpacted station and designated the 'outfall station'. S6 was only $6.25 \mathrm{~km}$ from S5. According to the current speed and direction in DYB (Zhang \& Zhou 2004), the main water bodies at both $\mathrm{S} 5$ and $\mathrm{S} 6$ came from the same source (from the south of the bay), but S6 was minimally influenced by the thermal effluent. The environmental conditions were very similar between the 2 stations, except temperature (Fig. 2b, Table 3). Therefore, S6 was chosen as the 'control station'.

\section{Temperature and PEA change during the study period}

Both the outfall and control stations showed temperature fluctuations between summers during the study period, but there was a clear trend that the temperature (especially surface) at the outfall station was increasingly higher than that at the control station (Fig. 3). At the outfall station, the surface temperature rose from $28.7^{\circ} \mathrm{C}$ in 1982 to $34.8^{\circ} \mathrm{C}$ in 2005 (the maximum was $35.5^{\circ} \mathrm{C}$ in 2004) (Fig. 3a). Stratification be-

Table 3. ANOVA comparison of environmental factors at the outfall and control stations during the investigation period. DIN: dissolved inorganic nitrogen; DIP: dissolved inorganic phosphorus

\begin{tabular}{|lcccccc|}
\hline & Temperature $\left({ }^{\circ} \mathrm{C}\right)$ & Transparency $(\mathrm{m})$ & Salinity & DIN $(\mu \mathrm{M})$ & DIP $(\mu \mathrm{M})$ & Silicate $(\mu \mathrm{M})$ \\
\hline S5 (Outfall) & $31.61 \pm 2.03$ & $2.55 \pm 0.58$ & $29.8 \pm 2.44$ & $4.26 \pm 2.62$ & $0.23 \pm 0.21$ & $19.93 \pm 9.32$ \\
S6 (Control) & $29.44 \pm 1.29$ & $2.99 \pm 0.82$ & $29.9 \pm 2.05$ & $3.10 \pm 2.21$ & $0.15 \pm 0.09$ & $19.05 \pm 9.39$ \\
p & 0.003 & 0.175 & 0.767 & 0.255 & 0.201 & 0.820 \\
\hline
\end{tabular}




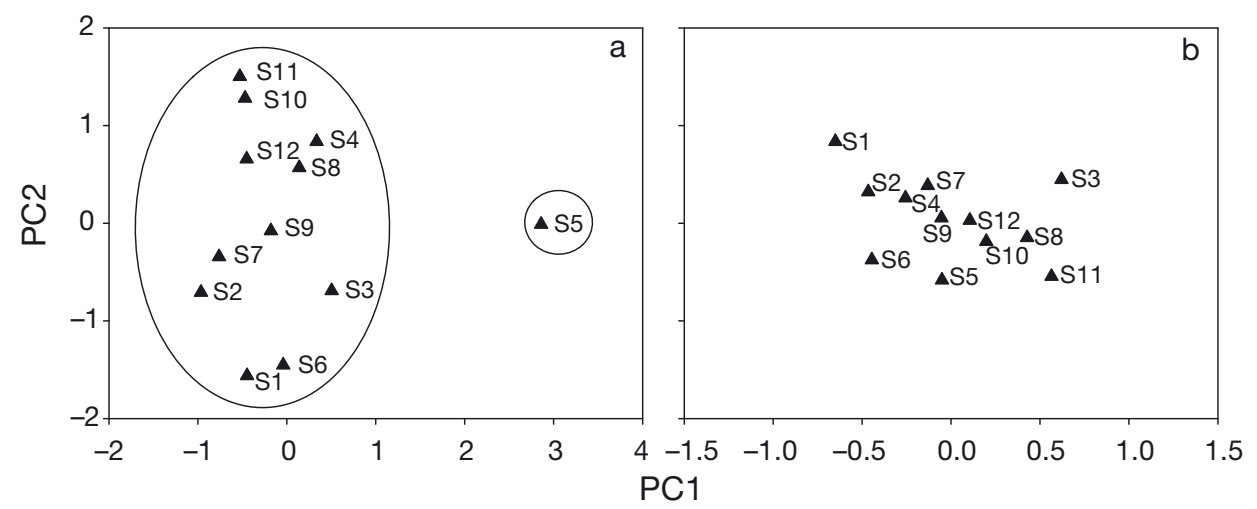

Fig. 2. Score plots for the first 2 principal components (PCs) obtained for the investigated stations from 1994 to 2005. (a) PC analysis by temperature; (b) PC analysis by depth, salinity and nutrients

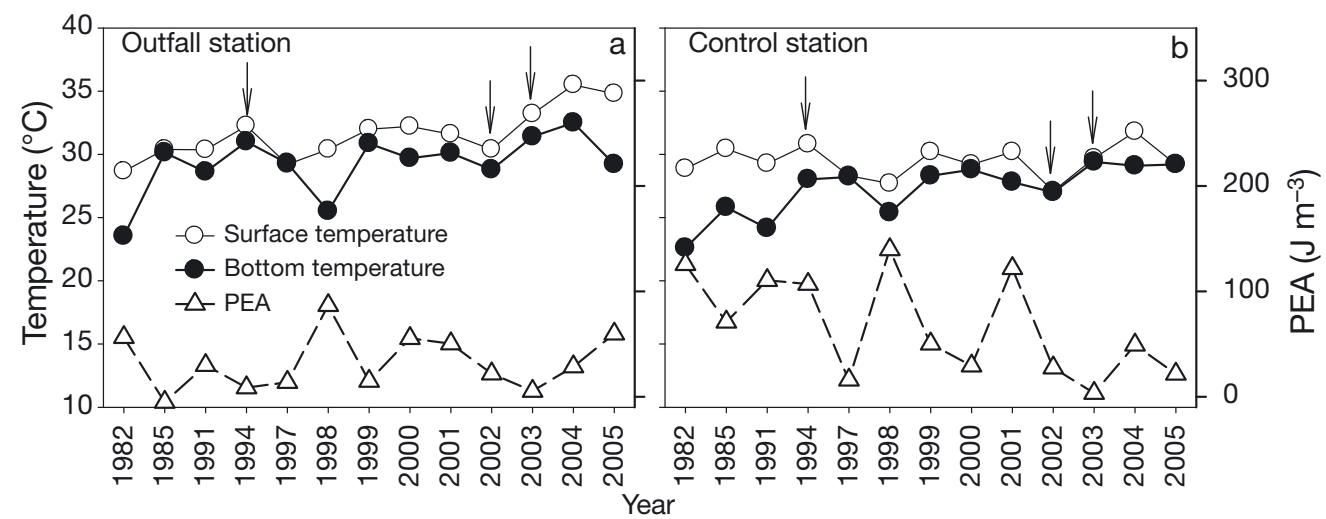

Fig. 3. Changes in temperature and potential energy anomaly (PEA) at (a) the outfall station and (b) the control station from 1982 to 2005 (3 arrows in each panel show the times when the Daya Bay nuclear power station and the first and second units of the Ling-Ao nuclear power station began operations)

came more serious after LNPS Unit 1 (2002) and Unit 2 (2003) went into operation; in 2005, the temperature difference between the surface and bottom reached $5.6^{\circ} \mathrm{C}$. The SST difference between the outfall and control stations was between $-0.2^{\circ} \mathrm{C}$ in 1982 and $5.6^{\circ} \mathrm{C}$ in 2005. These results indicated that the outfall station was strongly influenced by the NPS thermal effluent.

Based on the phases of NPS operation, the influence of thermal effluent could be divided into 3 phases at the outfall station: the pre-power plant phase (1982 to 1991) was prior to NPS operation, when the temperature was about $29.8 \pm 1.0^{\circ} \mathrm{C}$; the initial power plant phase extended from 1994 to 2001, during which the DNPS went into operation and the temperature was about $31.3 \pm$ $1.2^{\circ} \mathrm{C}$; and the 'additional' power plant phase (after the addition of the LNPS operation, 2002 to 2005), in which the temperature was about $33.5 \pm 2.3^{\circ} \mathrm{C}$.

At the control station, summer surface temperatures ranged from 27.1 to $31.8^{\circ} \mathrm{C}$, with a mean of $29.4 \pm 1.3^{\circ} \mathrm{C}$ (pre-power plant phase was about $29.5 \pm 0.8^{\circ} \mathrm{C}$, initial power plant phase was about $29.4 \pm 1.2^{\circ} \mathrm{C}$, additional power plant phase was about $29.5 \pm 1.9^{\circ} \mathrm{C}$ ), and no noticeable trend of change was found during the study period (Fig. 3b). This indicated that the water temperature at the control station was not affected by thermal effluent, and the base surface temperature was around $30^{\circ} \mathrm{C}$ in DYB in summer, close to the upper tolerance temperature of many phytoplankton species.

PEA (which is a stability index) fluctuated remarkably during the investigation period, and the water column was more stable at the control station than at the outfall station (Fig. 3). Water column stability could intensify with an increase in temperature (Fig. 3a), but this was not always the case. For example, the SST was $<30^{\circ} \mathrm{C}$ in 1982 and 1998 , even though strong stratification was found at both stations in those years before the NPS was in full operation. In contrast, even when the SST was $>30^{\circ} \mathrm{C}$ in 2003 and 2004, stratification was not very intense, especially for the outfall station (Fig. 3a). Considering the shallow depth (about $10 \mathrm{~m}$ ), the abundant thermal effluent could be a strong driver mixing the water at the outfall station. 


\section{Phytoplankton community shift during the study period}

\section{Phytoplankton community}

At the outfall station, phytoplankton species decreased from 50 in 1982 to 32 in 2005. Total phyto-

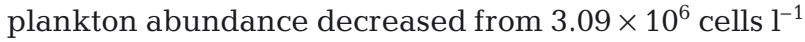
in 1982 to $3.0 \times 10^{5}$ cells $\mathrm{l}^{-1}$ in 2005 . Diatom species decreased at first and then increased, but their percentage decreased again after the start of the DNPS in 1994, and continued that trend after the LNPS went on-line in 2002 (Unit 1) and 2003 (Unit 2) (Fig. 4). In all accounts, the diatom proportion decreased from $82.0 \%$ in 1982 (41 species) to $56.3 \%$ in 2005 (17 species). The reverse results were found for dinoflagellates; the proportion of dinoflagellates in the phytoplankton community increased quickly, from $18.0 \%$ in 1982 (9 species) to $37.5 \%$ in 2005 (13 species). Total diatom cell abundance generally decreased from $3.07 \times 10^{6}$ cells $\mathrm{l}^{-1}$ in 1982 to $1.57 \times 10^{5}$ cells $^{-1}$ in 2005 . Dinoflagellates only accounted for $0.8 \%$ in 1982 , but increased to $44.2 \%$ in 2005 (the maximum of $52.3 \%$ was found in 2004, a 65-fold change), when the dinoflagellate cell abundance was $10^{5}$ cells $\mathrm{l}^{-1}$. In these phytoplankton assemblages, only a few other algae were found sporadically, and they only represented a very small proportion (0 to $6.3 \%$ ). But, in the additional power plant phase, they decreased again in 2002 and 2003, and then increased thereafter.
At the control station, a similar trend was found concerning the change in species numbers during the study period, whereby the total number of phytoplankton species dropped from 61 in 1982 to 25 in 2005. The diatom proportion decreased from $82.0 \%$ in 1982 (50 species) to $60.0 \%$ in 2005 (15 species), and the dinoflagellate proportion increased from $18.0 \%$ in 1982 (11 species) to $36.0 \%$ in 2005 (9 species), with some fluctuation. In terms of cell abundance, the percentage of dinoflagellate cell abundance increased from $0.4 \%$ in 1982 to $16.6 \%$ in 2005 (a 40-fold change), but the cell abundance was only

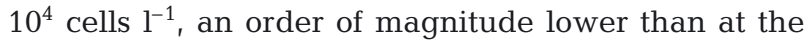
outfall station.

A similar outfall-control contrast was observed in diatoms and dinoflagellate cell abundance. In most years after the NPS began to operate (1994 to 2005), the cell abundance of dinoflagellates was higher at the outfall station than at the control station, but diatom and total phytoplankton abundances were reversed. From 1994 to 2005, the diatom/dinoflagellate cell abundance ratio was $33.0 \pm 46.0$ and $109.6 \pm$ 217.5 at the outfall station and control station, respectively. These results indicated that the phytoplankton community experienced a smaller magnitude of species composition change at the control station than at the outfall station after the NPS began operation, and the phytoplankton community experienced a diatom to dinoflagellate abundance shift at the outfall station.
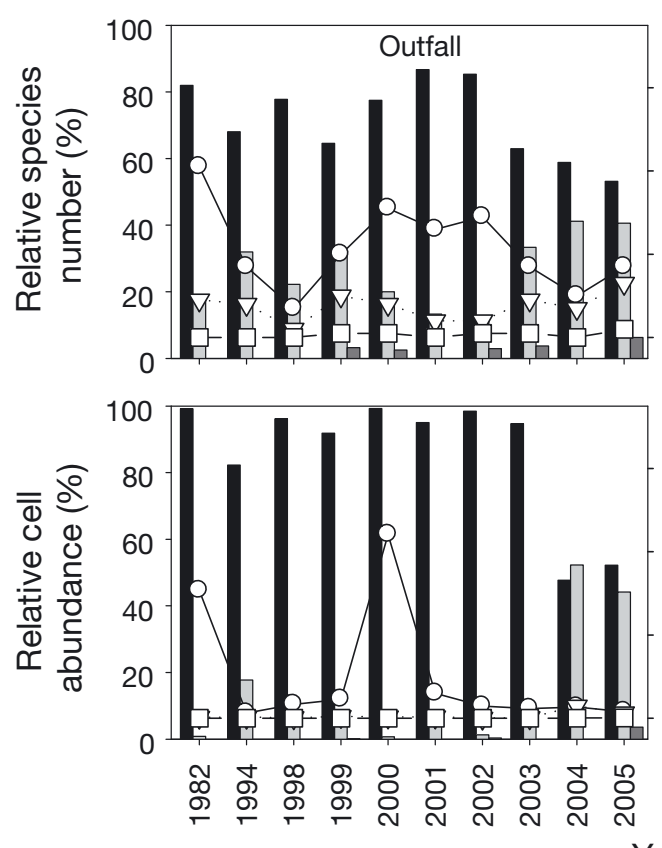

Year
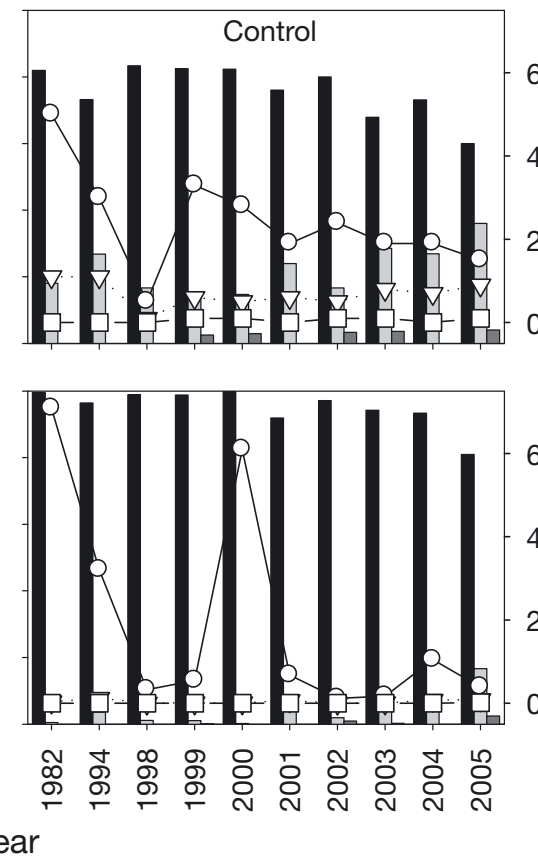

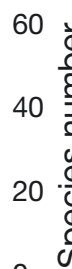

Percentage

- Diatom

$\square$ Dinoflagellate

$\square$ Other algae

Species number and cell abundance

-O- Diatom

$\nabla$ ' Dinoflagellate

$\neg-$ Other algae

Fig. 4. Phytoplankton composition (percentage, species numbers and cell abundance) at the outfall and control stations in the summers of different years 
Species shift during the study period

Dominant species were determined according to their cell abundance and corresponding proportion (Table 4). Prior to the operation of the first nuclear power plant, the phytoplankton community in DYB was dominated by diatoms, such as Chaetoceros compressus, Ch. distans, Ch. affinis, Ch. weissflogii, Pseudo-nitzschia delicatissima and Rhizosolenia delicatula. The phytoplankton community structure was very similar between the outfall and control stations, Chaetoceros spp. being the absolute dominant species in this phase. In the initial power plant phase, species composition was, in general, still similar between the 2 stations, with diatoms dominating the phytoplankton community, but the dominant species shifted a little exhibiting a somewhat upward trend in species diversity, including Thalassionema nitzschioides, T. frauenfeldii, P. delicatissima, P. pungens, Skeletonema spp. and Chaetoceros spp. It is noteworthy that Ceratium furca appeared as the dominant species only at the outfall station just after the DNPS went on-line (1994) and then disappeared. These results indicate that the phytoplankton assemblage in DYB could adapt to temperature elevation to a certain extent. In the additional power plant phase, the influence of thermal effluent intensified after the LNPS went on-line. Dinoflagellates evidently increased and became dominant at the outfall station, with a 2 yr lag since the LNPS was put in operation, including C. furca, C. fusus, C. trichoceros, C. breve v. parallelum, C. macroceros, Protoperidinium depressum and Dinophysis caudate. In contrast, fewer dinoflagellates were dominant at the control station (Table 4). By comparison, phytoplankton species composition obviously shifted at the outfall station.

In addition, among diatoms and dinoflagellates, the genus and species of the phytoplankton observed at the outfall station changed notably after the NPS began operation (Fig. 5). Some species of Chaetoceros,

Table 4. Changes in dominant species at the outfall and control stations before and after the nuclear power plant went on-line. Bold print indicates a dinoflagellate species. $\Delta T$ : temperature difference between outfall and control stations; C.a.: cell abundance (\%). Genera are Ch.: Chaetoceros; P.: Pseudo-nitzschia; T.: Thalassionema; R.: Rhizosolenia; C.: Ceratium; S.: Skeletonema; B.: Bacteriastrum; Pro.: Protoperidinium; E.: Eucampia; D.: Dinophysis

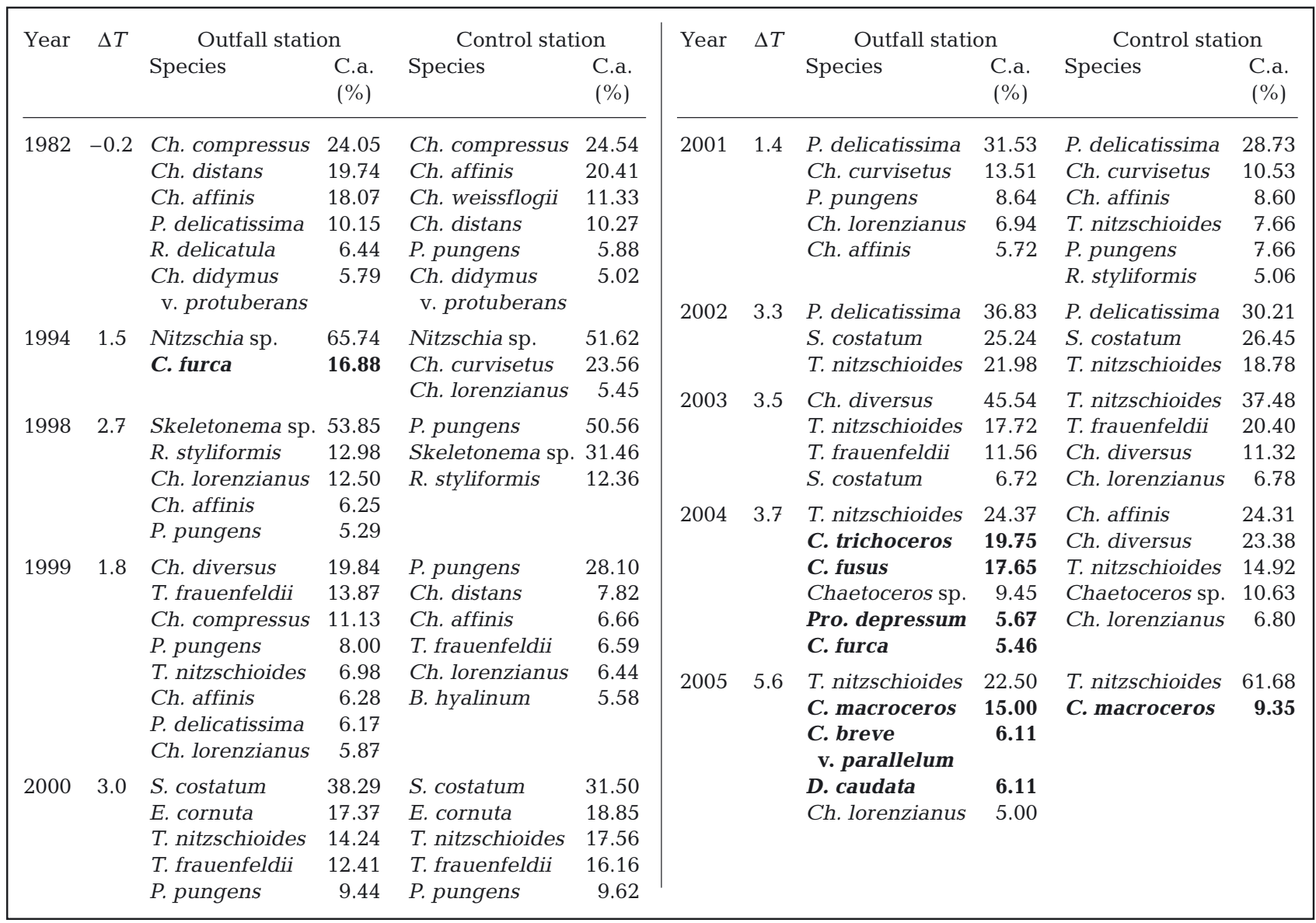




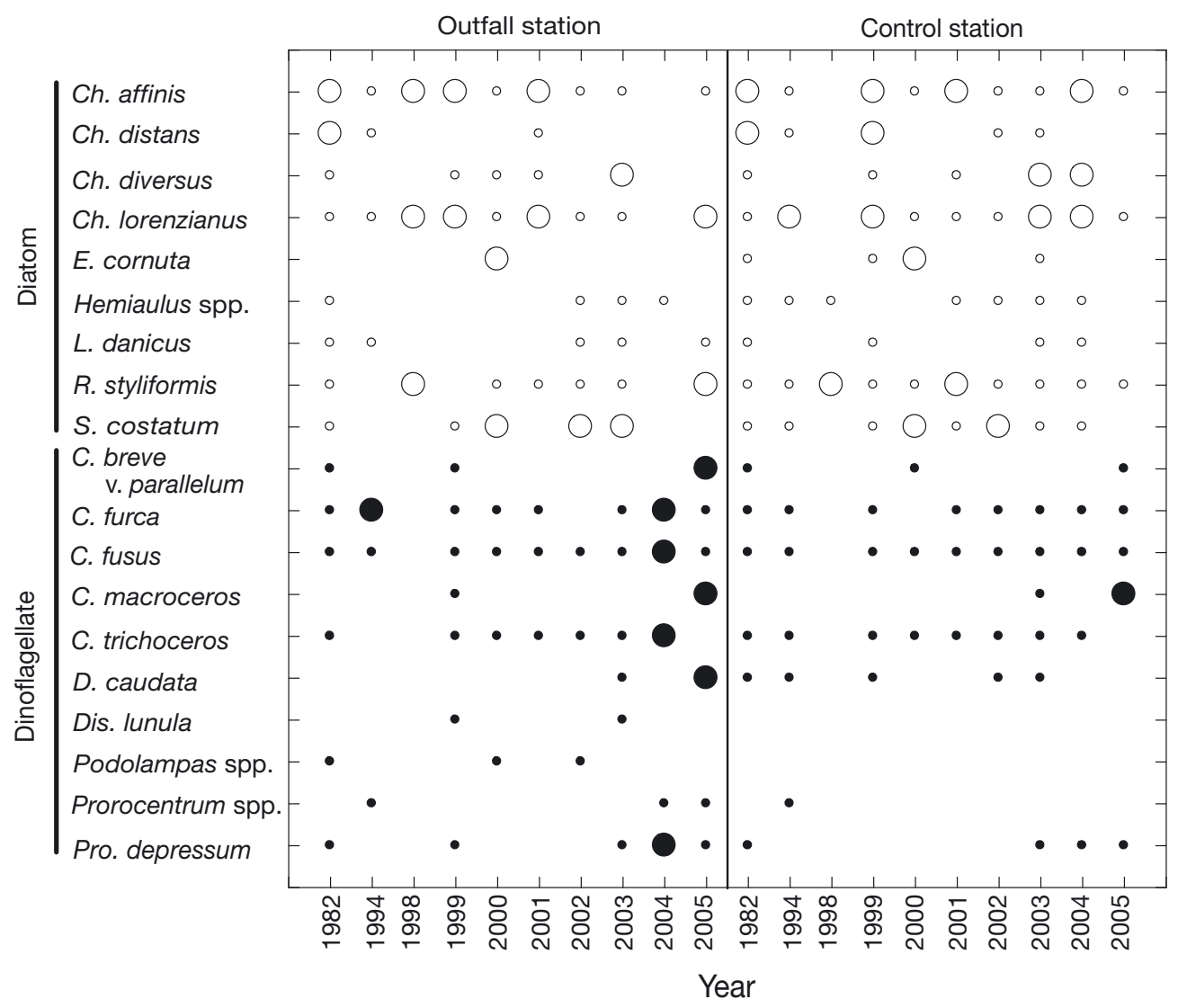

Fig. 5. Schematic diagram to show the shift in species at the outfall and control stations in the summer, from 1982 to 2005 . Genus names as in Table 4 (L.: Leptocylindrus; Dis.: Dissodinium). O: diatom dominant; 0 : dinoflagellate dominant; ○: diatom present; $\bullet$ : dinoflagellate present

such as Ch. affinis, Ch. distans, Ch. diversus and Ch. lorenzianus, dominated during pre- and initial power plant phases and decreased gradually and even disappeared during the additional power plant phase at the outfall station, while they were still dominant species at the control station. Less Eucampia cornuta was found at the outfall than at the control station. Some diatom species such as Hemiaulus spp. and Leptocylindrus danicus disappeared during the first several years after the NPS started at the outfall station. Then they were found again after 2002, but most of these diatoms were eurythermal, warm-water species, adaptable to the elevated temperature. Rhizosolenia styliformis and Skeletonema costatum increased and were dominant during the additional power plant phase at the outfall station, but decreased at the control station.

Some dinoflagellate species, such as Ceratium furca, C. fusus, C. trichoceros, C. breve v. parallelum, C. macroceros, Dinophysis caudate and Protoperidinium depressum increased and were dominant at the outfall station during the additional power plant phase. Although they also appeared at the control station, they did not become dominant species at the control station, with the exception of C. macroceros in 2005. After the NPS was running, Dissodinium lunula, Podolampas spp. and Prorocentrum spp. appeared at the outfall station, but they were hardly found at the control station. Most of these dinoflagellate species are causative species of harmful algae blooms (HAB).

\section{Relationship between phytoplankton community structure and environmental factors}

Correlation analyses were carried out for both outfall and control stations for percentages of species numbers and cell abundance of diatoms and dinoflagellates versus environmental factors, including temperature, PEA, salinity and nutrients. No significant relationship was found between phytoplankton and environmental factors except water temperature. The results showed that percentages of species number, and cell abundance were significantly correlated with temperature at the outfall station $\left(R^{2}>0.65\right)$, 


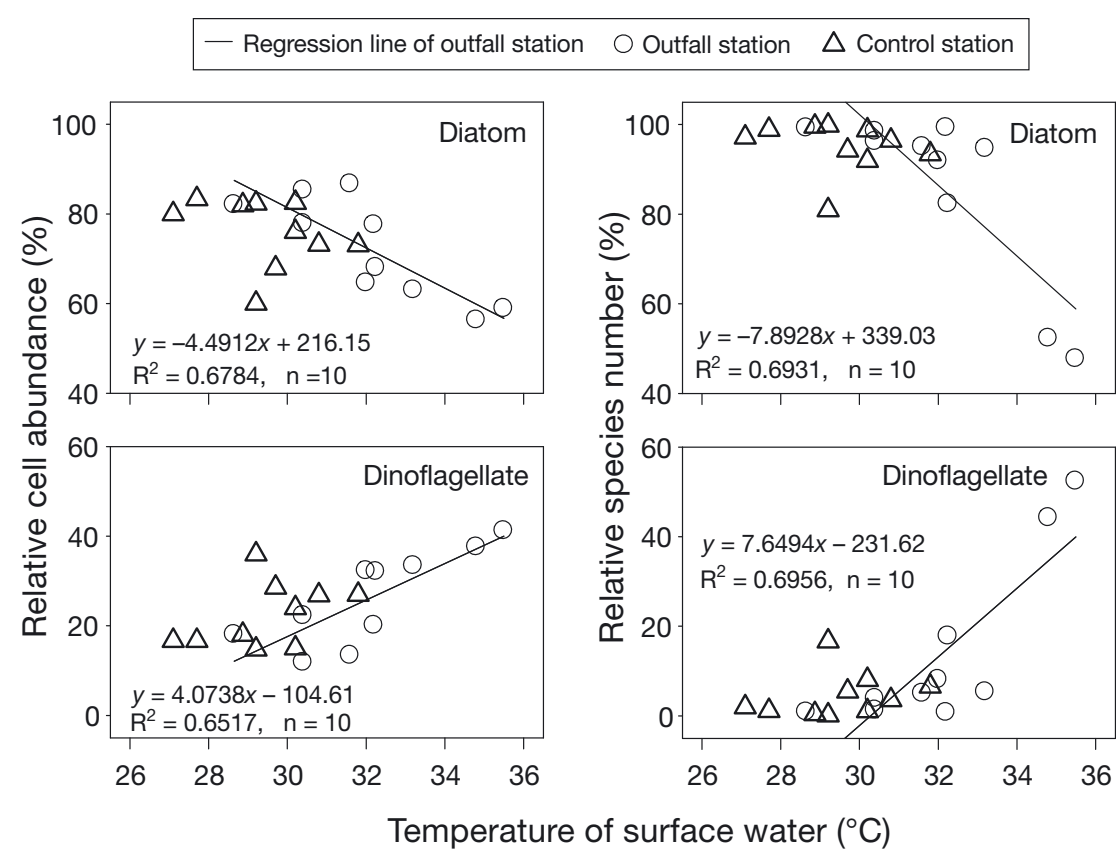

Fig. 6. Correlation between temperature and relative dominance (percent total numbers of species and cell abundance) of diatoms and dinoflagellates nitzschia depressum and Dinophysis caudate became the dominant species at the outfall station, with abundances of $>10^{4}$ cells $\mathrm{l}^{-1}$, while less dinoflagellate species appeared at the control station, except for Ceratium macroceros in 2005 (Table 4). The relationship between temperature and phytoplankton clearly showed that a temperature rise was beneficial to dinoflagellates, but detrimental to diatoms (Fig. 6). Such a relationship has also been reported in the North Sea (Beaugrand et al. 2003). High positive correlation has been reported between dinoflagellate growth and temperature increases in the North Sea, the genera Ceratium, Protoperidinium and Dinophysis were able to respond quickly to a rise in temperature, but the diatom was relatively stable in the annual cycle (Edwards \& Richardson 2004).

Thermal discharge has previously been shown to cause shifts in the negatively for diatoms and positively for dinoflagellates (Fig. 6).

Diatoms dominated the phytoplankton community when temperature was $<30^{\circ} \mathrm{C}$. When temperature reached $32^{\circ} \mathrm{C}$, the dinoflagellate species clearly increased, but their cell abundance was still low. When temperature was $>35^{\circ} \mathrm{C}$, dinoflagellates, such as Ceratium, Dinophysis and Protoperidinium species, significantly increased and dominated the community. This trend fits both outfall and control stations, except that temperature rarely reached $35^{\circ} \mathrm{C}$ at the control station.

\section{DISCUSSION}

The present study, carried out for over 23 yr, showed that thermal changes driven by power plant outflow cause a significant community shift from diatom to dinoflagellate dominance. When water temperature in the effluent-receiving waters reached a temperature $>35^{\circ} \mathrm{C}$ and $3.7^{\circ} \mathrm{C}$ above the adjacent waters in summer, the species numbers and cell abundance of dinoflagellates markedly increased, reaching values much higher than those in adjacent waters. The ratio of dinoflagellate/diatom cell abundance at the outfall station was significantly higher than that at the control station. This clearly indicates that the rise in temperature favored dinoflagellates over diatoms. In terms of species numbers, the same trend was also found. After the LNPS went on-line, Ceratium spp., Pseudo- overall phytoplankton community, because an elevation in temperature may have positive effects on some phytoplankton species, but negative effects on others, due to the differential optimal growth temperatures for different phytoplankton species (Krishnakumar et al. 1991). In the Bering Sea, an unusual rise in surface temperature of between 2.5 and $3.0^{\circ} \mathrm{C}$ occurred between early July and November 1997. As a result, the normally diatom-dominated phytoplankton community became dominated by the coccolithophorid Emiliania huxleyi, triggering a trophic cascade catastrophe (Sukhanova \& Flint 1998). Phytoplankton community shifts influenced by thermal effluents have also been observed in Asian waters, e.g. northern Taiwan (Lo et al. 2004) and India (tropical zone) (Krishnakumar et al. 1991).

A rise in temperature could also increase the water column stability. Previous studies showed that phytoplankton composition could change according to water column stratification: dinoflagellates preferring stable waters and diatoms preferring well-mixed waters (Margalef 1978, Jones \& Gowen 1990). An increasing number of studies have shown that dinoflagellate growth is inhibited by turbulence, which causes cell cycle arrest in dinoflagellates (Llaveria et al. 2009 and references therein). In addition, water stratification could depress the resupply of nutrients from deeper waters, giving dinoflagellates a competitive advantage over diatoms under limited nutrient conditions. However, the outfall versus control station difference in 
dinoflagellate dominance that we observed at DYB was not due to water stratification associated with a rise in temperature at the outfall station. Even though strong stratification $\left(\varphi>80 \mathrm{~J} \mathrm{~m}^{-3}\right)$ occurred in 1982, 1991, 1994, 1998 and 2001 at the control station, the phytoplankton community there was still dominated by diatoms. Influenced by strong thermal effluent flow, water at the outfall station was less stable than at the control station.

In DYB, a previous study based on short-term observations revealed that the structure and function of the marine ecosystem have been degenerating since the inception of NPS operations (Wang et al. 2003). Some micro-phytoplankton have decreased and even disappeared (e.g. the genera Amphiprora, Bellerochea, Chrysanthemodiscus and Schroederella), while some nano-species (such as Pseudo-nitzschia delicatissima, P. pungens, Thalassionema subtilis) have grown to dominance in the phytoplankton community (Liu et al. 2003). In the summer, the phytoplankton community showed low species diversity and mainly consisted of coastal warm-water species, as a result of the influence of the thermal effluent. For instance, Chaetoceros species (whose optimal temperature was about $30^{\circ} \mathrm{C}$ ) were replaced by some eurythermal species, such as $P$. delicatissima, Skeletonema costatum and T. nitzschioides (Xu et al. 2001, Sun et al. 2006). Some previous studies have reported that many microalgae cannot tolerate temperatures $>33^{\circ} \mathrm{C}$, but, under the influence of thermal effluent, an increase of $3^{\circ} \mathrm{C}$ above the ambient temperature should be safe for aquatic organisms in tropical and subtropical zones in the summer (Krishnakumar et al. 1991 and references therein). Data from our present study also show that a phytoplankton community can endure a certain degree of temperature increase. During the period when only the DNPS was in operation (initial power plant phase, 1994 to 2001) and the temperature ranged from 29.2 to $32.3^{\circ} \mathrm{C}$, the dominant species changed from Chaetoceros spp. (pre-power plant phase) to Thalassionema spp., but the general phytoplankton composition was still dominated by diatoms and Chaetoceros spp. was always an important component from 1982 to 2002. After the 2 LNPS units were added (additional power plant phase, 2002 to 2005), however, the temperature in the effluentreceiving waters rose higher than $35^{\circ} \mathrm{C}\left(35.5^{\circ} \mathrm{C}\right.$ in $2004)$ and $3.7^{\circ} \mathrm{C}\left(5.6^{\circ} \mathrm{C}\right.$ in 2005$)$ above the adjacent waters in summer and the phytoplankton community structure showed significant change. Our results strongly suggest that the thermal effluents significantly affected the phytoplankton community at the outfall station. Based on our observations, $35^{\circ} \mathrm{C}$, or a differential relative to normal temperature (i.e. at the control station) of $3.7^{\circ} \mathrm{C}$, seems to be the upper tolerance limit for the phytoplankton community in DYB.
In the coastal marine ecosystem, phytoplankton communities have shown shifts associated with changes in environmental conditions such as global warming and eutrophication, generally with diatoms decreasing and dinoflagellates increasing. For instance, Liu et al. (2008) have reported on such a trend in Jiaozhou Bay, a temperate coastal zone. Phytoplankton community change has also been reported along the coast of California as a result of environmental changes, with the red-tide-forming dinoflagellate Cochlodinium increasing in frequency and cell abundance, indicating a diatom to dinoflagellate shift in this region as well (Curtiss et al. 2008). It has been estimated that the global mean temperature will increase by $1.9^{\circ} \mathrm{C}$ in the next $100 \mathrm{yr}$ (www.cotf.edu/ete/modules/climate/GCremote3.html). Regional temperature hikes may be much greater. For instance, it has been estimated that the western region of the USA could become $3^{\circ} \mathrm{C}$ warmer in the next $100 \mathrm{yr}$. With such increases, phytoplankton community structure may shift toward warm-water species, such as some species of dinoflagellates. Further impact may result from water stratification associated with the warming of surface waters. Based on our results (Fig. 6), the contribution of diatom species numbers and cell abundance should decrease by about 9 to $15 \%$ and 13 to $24 \%$, respectively. However, the contribution of dinoflagellate species numbers and cell abundance should increase by about 8 to $15 \%$ and 12 to $23 \%$, respectively. A similar diatom to dinoflagellate shift may occur in other natural marine environments. The effects of eutrophication can be attributed to a nitrogen increase and corresponding silicate deficiency. A 1:1 molar ratio of $\mathrm{N}$ to $\mathrm{Si}$ is generally considered the tipping point in favor of diatoms (when the ratio is $<1$ ) over non-diatom phytoplankton (when the ratio is $>1$ ) (Justić et al. 1995). In our case, the $\mathrm{N}$ to Si molar ratio was $>1$ during our study period, suggesting that a $\mathrm{Si}$ deficiency was unlikely the cause of the increase in the dinoflagellate contribution to the phytoplankton community. Regardless, a rise in temperature may cause or aggravate such a phytoplankton shift, especially in tropical oceans, where small temperature elevations may exceed the physiological tolerances of organisms (such as dinoflagellate symbionts) (Walther et al. 2002). It is also noteworthy that the dinoflagellate species that seemed to increase in the outfall water were those known to form HABs in various places around the world (Alkawri \& Ramaiah 2010). It has been reported that dinoflagellate blooms in DYB have increased during recent years (Liu et al. 2003). Our results suggest that a rise in temperature, as a consequence of NPS operations or global warming, will probably lead to a higher likelihood of dinoflagellate HAB occurrences and trophic cascade consequences. 
Acknowledgements. We thank the anonymous reviewers for their very helpful comments on this work. We also thank Dr. Yan Tong for stratification analysis, and Mr. Liu Jing-Wei for helping with data analysis. This work was supported by CAS for Key Topics in Innovation Engineering (KZCX2-YWJS206), the CAS/SAFEA International Partnership Program for Creative Research Teams (KZCX2-YW-T001), the Natural Science Foundation of China (Nos. 41076096 and 40828006) and the Guangdong Natural Science Fund (2010B031900039).

\section{LITERATURE CITED}

Alkawri AAS, Ramaiah N (2010) Spatio-temporal variability of dinoflagellate assemblages in different salinity regimes in the west coast of India. Harmful Algae 9:153-162

Beaugrand G, Brander KM, Lindley JA, Souissi S, Reid PC (2003) Plankton effect on cod recruitment in the North Sea. Nature 426:661-664

Cai RS, Zhang QL, Qi QH (2009) Spatial and temporal oscillation and long-term variation in sea surface temperature field of South China Sea. J Oceanogr Taiwan 28:559-568 (in Chinese, with English abstract)

Chen C, Shi P, Mao QW (1996) Satellite remote sensing survey of chlorophyll concentration of surface waters in Daya Bay. In: Zuo RL (ed) Sustainable utilization of oceanic bioresources at Daya Bay. Science Press, Beijing, p 56-59 (in Chinese)

Curtiss CC, Langlois GW, Busse LB, Mazzillo F, Silver MW (2008) The emergence of Cochlodinium along the California coast (USA). Harmful Algae 7:337-346

Descy JP, Mouvet C (1984) Impact of the Tihange nuclear power plant on the periphyton and the phytoplankton of the Meuse River (Belgium). Hydrobiologia 119:119-128

Edwards M, Richardson AJ (2004) Impact of climate change on marine pelagic phenology and trophic mismatch. Nature 430:881-884

Eloranta PV (1983) Physical and chemical properties of pond waters receiving warm-water effluent from a thermal power plant. Water Res 17:133-140

Gomez N (1995) Changes in the phytoplankton of the reservoir Embalse Rio Tercero (Prov. Cordoba, Argentina) as a result of the nuclear power plant operating there. Acta Hydrobiol 37:129-139

Hays GC, Richardson AJ, Robinson C (2005) Climate change and marine plankton. Trends Ecol Evol 20:337-344

Hoegh-Guldberg O (1999) Climate change, coral bleaching and the future of the world's coral reefs. Mar Freshw Res 50:839-866

Huang XN, Zhu ZH, Xu MC, Jing QZ (1998) Variation of water temperature in the southwestern Daya Bay before and after the operation of Daya Bay nuclear power plant. In: Pan JP, Wang ZD (eds) Annals research reports (II) of marine biology research station at Daya Bay, the Chinese Academy of Sciences. Science Publishing Company, Beijing, p 102-112 (in Chinese, with English abstract)

IPCC (Intergovernmental Panel on Climate Change) (2007) Climate change 2007: the physical science basissummary for policy makers. Contribution of Working Group I to the 4th assessment report of the Intergovernmental Panel on Climate Change. IPCC Secretariat, Geneva

Jones KJ, Gowen RJ (1990) Influence of stratification and irradiance regime on summer phytoplankton composition in coastal and shelf seas of the British Isles. Estuar Coast Shelf Sci 30:557-567

Justić D, Rabalais NN, Turner RE, Dortch Q (1995) Changes in nutrient structure of river-dominated coastal waters: stoichiometric nutrient balance and its consequences. Estuar Coast Shelf Sci 40:339-356
Krishnakumar V, Sastry JS, Swamy GN (1991) Implication of thermal discharges into the sea-a review. Indian J Environ Prot 11:525-527

Liu S, Lian JS, Huang H, Huang LM, Li T (2003) Phytoplankton community change in Daya Bay during the past 20 years. In: Ho KC, Lu SF, Yu TS, Wong KF (eds) Recent advances in the prevention and management of harmful algal blooms in the South China Sea. Association on Harmful Algal Blooms in the South China Sea, Hong Kong, p 17-21

Liu S, Huang LM, Huang H, Lian JS, Long AM, Li T (2006) Ecological response of phytoplankton to the operation of Daya Bay nuclear power station. Mar Environ Sci 25(2):9-12, 25 (in Chinese, with English abstract)

Liu D, Sun J, Zhang J, Liu G (2008) Response of the diatom flora in Jiaozhou Bay, China to environmental changes during the last century. Mar Micropaleontol 66:279-290

> Llaveria G, Figueroa RI, Garcés E, Berdalet E (2009) Cell cycle and cell mortality of Alexandrium minutum (Dinophyceae) under small-scale turbulence conditions. J Phycol 45: $1106-1115$

Lo WT, Hwang JJ, Hsu PK, Hsieh HY, Tu YY, Fang TH, Hwang JS (2004) Seasonal and spatial distribution of phytoplankton in the waters off nuclear power plants, North of Taiwan. J Mar Sci Technol 12:372-379

Margalef R (1978) Life forms of phytoplankton as survival alternatives in an unstable environment. Oceanol Acta 1: 493-509

Mercado LM, Gomez N (1999) Effects of a nuclear power plant on phytoplankton structure of the lower Paraná River. Interciencia 24:36-41

Niemi GJ, McDonald ME (2004) Application of ecological indicators. Annu Rev Ecol Evol Syst 35:89-111

Richardson AJ, Schoeman DS (2004) Climate impact on plankton ecosystems in the Northeast Atlantic. Science 305:1609-1612

Singh KP, Malik A, Mohan D, Sinha S (2004) Multivariate statistical techniques for the evaluation of spatial and temporal variations in water quality of Gomti River (India) - a case study. Water Res 38:3980-3992

Sukhanova IN, Flint MV (1998) Anomalous blooming of coccolithophorids over the eastern Bering Sea Shelf. Oceanology (Moscow) 38:502-505

Sun CC, Wang YS, Sun S, Zhang FQ (2006) Dynamic analysis of phytoplankton community characteristics in Daya Bay, China. Acta Ecol Sin 26(12):3948-3958

Tang CL, Zheng ZY, You DW, Deng S, Huang YR (2006) Analysis of SST variation in recent 30 years in the Zhujiang River estuary. J Oceanogr Taiwan 25:96-101 (in Chinese, with English abstract)

UNESCO (United Nations Educational, Scientific and Cultural Organization) (1994) Protocols for the joint global ocean flux study (JGOFS) core measurements. UNESCO, Paris

Walther GR, Post E, Convey P, Menzel A and others (2002) Ecological responses to recent climate change. Nature 416: 389-395

Wang ZD, Lian JS, Hu JX, Wei GF (2003) Characteristics of degraded ecosystem in Daya Bay China. Ecol Sci 11: 313-320 (in Chinese, with English abstract)

Xu GZ (1989) Environments and resources of Daya Bay. Anhui Press of Science and Technology, Anhui (in Chinese)

Xu N, Chen JF, Wang ZH, Wang Y, Huang WJ, Qi YZ (2001) Dynamic analysis on several algal bloom events in Daya Bay of Guangdong. I. Process of algal bloom and its relationship with environmental factors. Mar Environ Sci 20(2): 1-6, 12 (in Chinese, with English abstract)

Zhang WQ, Zhou RM (2004) Thermal impact analysis of discharge of circulating cooling water at Daya Bay nuclear power station (GNPS) and Ling Ao nuclear power station (LNPS). Radiat Prot 24:257-262 (in Chinese, with English abstract) 